\title{
GROSS DOMESTIC PRODUCT, EDUCATION, UNEMPOYMENT AND POVERTY: EVIDENCE FROM SOUTH SUMATERA PROVINCE, INDONESIA
}

\author{
Muhammad Yusuf \\ Business Administration Department, Business Management Study Program, \\ Polytechnic State of Sriwijaya \\ E-mail : m.yusuf@polsri.ac.id
}

\begin{abstract}
This study determine the effect of Gross Domestic Product (GDP), education level and unemployment rate on the poverty in the South Sumatra Province in year of 2013 - 2018. The method uses panel data analysis using Eviews program with combination time-series data and cross-section data using panel data through fixed effects Model. The data obtained from the Central Statistic Bureau of Indonesia. The results showed that the GDP variable and the education level are negative and significant effect on poverty in the South Sumatra Province, the unemployment level is positive and significant effect on poverty in the South Sumatra. The information and the policy considerations related parties to improve the system of growth and development in the South Sumatra especially, and Indonesia in general.
\end{abstract}

Keywords : Gross domestic product, Education, Unemployment, Poverty

\section{Introduction}

The purpose of economic development is to improve the equitable welfare of society. The Indonesian government's efforts to realize the welfare of the community are to provide autonomy to regional governments based on broad autonomy, real and responsible so that the regions have the authority to regulate their local government based on their community's aspirations. For these purposes, it's needed the better planning by utilizing existing resources. According to the views of economists, there are at least four factors that affecting economic growth, they are: population, capital, land and natural wealth, and also the level of education and technology that used, although the economic growth may depend on many factors [1].

South Sumatera Province is one of the provinces in Indonesia that get regional autonomy. Economic growth in South Sumatra Province since 2013 - 2018 tends to increase. From terms of production, growth is dominated by agriculture, forestry, and fisheries that grew 10.18 percent, while in terms of expenditure is more caused by exports that grew 34.92 percent.

Economic growth use one of the indicators used to look at the symptoms of economic growth in a country or region is the Gross Domestic Product (GDP) [2]. Through the process of economic growth, can see the economic activities that have been done and achieved in South Sumatra during a certain period. In addition, the rate of economic growth can also be attributed to the rate of population growth because in principle economic growth should be enjoyed by the population. Population needs to be considered, because in addition as a subject, the population is also the object of development.The changes that occur in the aspect of population will affect the development process and the objectives to be achieved.

High population growth rates will lead to a rapid increase in the number of workforces and cause the number of jobs to become narrow or few. It can lead to unemployment problems that exist in an area. High unemployment rates in a region can cause to increased poverty and show the less successfull of the development. The percentage of poverty rate in South Sumatra fluctuated, which in 2013 by 14.80 percent decreased to 13.95 percent in 2014 , and 13.48 percent in 2015. However, the poverty rate increased again in 2016 by 14.06 percent, 13.62 
percent in 2017 and increased again in 2018 by 14.25 percent [3].

Economic development is an attempt to improve the living standard of a nation that is often measured by the high low real incomes per capita. The purpose of economic development in addition to raising real incomes, as well as to increase productivity [4]. In carrying out its development activities, there are factors that determine the success or failure of the development process that done by a country. According to Irawan and M. Suparmoko, these factors can be classified into two kinds, namely economic factors and non-economic factors that include the legal system, education, health, religion, government, and etc. To achieve the success of development activities, then there must be performance optimization to these factors.

Economic growth is capacity increase in a long-term of a country to provide a range of economic goods to its population [5]. The increase in capacity was determined by the presence advancement or adjustments of technology, institutional (institutional) and ideological. There are six characteristics of process in economic growth that done by developing countries that have become developed country, including:

1. High per capita output growth rate and population growth.

2. High factor productivity increase rate.

3. High level of structural economic transformation.

4. The level of social transformation and ideology is high.

5. There is a tendency for countries that start or that have already advanced of its economies to try to add the parts of its other world as a marketing area and source of new raw materials.

6. Limited spread of economic growth which reaches only about one third of the population.

Based on macroeconomic analysis, economic growth has two different understanding. On the one hand, economic growth is used to describe an economic that has experienced economic development and reached a high level of prosperity [6]. On the other hand, economic growth aims to illustrate the economic problems faced by a country or region in the long term. The problem of economic growth is divided into three aspects, they are: The first aspect is sourced from the differences between the potential growth rate that can be achieved with the level of economic growth that has achieved. Investments made at this time can increase inventory of capital goods in the future, so the potential of a country or region to produce goods and services will increase. Technological advances, population growth and productivity development can also increase production of goods and services. However, that rising of factors do not necessarily increase economic growth. The second aspect is increasing the potential for growth. When a country or region will increase the growth of GDP to a certain amount to reduce unemployment problems, but in reality the growth of GDP achieved is not as planned. As a result, unemployment problems can not be resolved, causing that State or region to think of ways to accelerate the pace of economic growth. The third aspect is the determination of the prevailing economic growth from one year to the next year. Changes in economic growth is faced a country or region are fluctuating. At one time it can grow rapidly, and in certain times can run slowly or lower than the previous year. Low economic growth can increase the poverty rate.

Poverty is a condition where someone can not enjoy all kinds of choices and opportunities in the fulfillment of basic needs, such as not being able to meet health, decent living standards, freedom, self-esteem and respect as others, and the future gloom of the nation and state. Poverty is a problem faced by all countries, especially in developing countries like Indonesia. This is because poverty is multidimensional, it means that because human needs are various, then poverty also has many primary aspects including the poverty of assets, socio-political organizations, knowledge, and skills and also secondary aspects such as the poverty of social networks, sources Finance, and information.

The level of poverty can be divided into poverty of Absolute, Relative and Cultural . While the cause of poverty is divided into four 
mahzab, namely Individual explanation, Familial explanation, Subcultural explanation, and Structural explanation. At least some of the problems source that must be resolved in order to can resolve all the problems as follows: first, because of poor, someone must have a small income. Because the income is lower, the purchasing power of information and knowledge is low. This low purchasing power of information and knowledge, will cause the poor not to have enough knowledge. Less knowledge, will cause a person's productivity to be small. Because of its small productivity, it will cause them to be fall poor again. Second, because of poor, someone will only have a small savings. Because having small savings, will make the ownership of someone's capital becomes low which will cause low production and low income. Because the income is lower, it will cause them to be fall poor again. Third, because of poor, someone will only have low consumption ability. Low consumption ability will make a person unable to meet the needs of board, clothing, and food properly. This will also have an impact on the bad of someone's nutritional status. A person with a bad nutritional status will only have a bad working productivity will cause his production to be low, thus will lead to be fall poor again [7].

Community welfare can be measured by using the national income per capita of a country or region. In a regional or local area, then the welfare of the community is measured through the Gross Domestic Product (GDP) per capita. Economic growth measured by GRDP per capita is determined by several factors, among others: Land and Natural Resources, the number and quality of population and labor, capital, technology level, social system and community attitudes. Population and labor quality can be improved through education. If the quality of education of a country or region is low, it will cause the development process to be hampered. This is because education is closely related to character building and also maintains the human identity of a country or region. A country's progress indicator is the development of the education world which is always be a top priority because education is a means to facilitate in entering the labor market.
Population growth and labor force growth (which occurred several years later after the population growth) has traditionally been regarded as one of the factors increasing the economic growth. the Larger amount of workforce it means will add the amount of productive forces, while greater population growth means increasing the size of its domestic market. In other words, the more labor force is used in the production process, the output of production will increase to some extent. In an internationally defined standard of understanding, what is meant by unemployment is a person who has been classified into the labor force who is actively looking for a job at a certain wage level, but can not get the job that he wants [5]. Unemployment is divided into 3 types based on the circumstances that cause it, such as [6]:

1. Frictional unemployment, is unemployment that caused by the actions of a worker to leave his or her work and find a better job or as he wishes.

2. Structural unemployment, is unemployment that caused by structural changes in the economy.

3. Conjuncture unemployment, is unemployment that caused by natural unemployment overload and prevailing as a result of a reduction in aggregate demand

The forms of unemployment are [8]:

1. Open unemployment, is a workforce capable and willing to work, but not available the suitable job.

2. Underemployment, is the workforce who work full nominally but its productivity is low, so the reduction in its working hours has no meaning for the production as a whole.

3. Weak labor (impaired), is a full-time workforce, but the intensity is weak due to malnutrition or illness.

4. Unproductive workers, are the workers who are able to work productively but can not produce something good.

Unemployment can affect the poverty levels in a various ways, among other things [9]:

1. If the household has a liquidity limit, which means that current consumption is heavily influenced by current income, then 
unemployment will directly affect the income poverty rate and the consumption poverty rate.

2. If households do not encounter liquidity restrictions, which means that current consumption is less influenced by current income, so the increase of unemployment will lead to an increase in poverty in the long term, but not very influential in the short term.

Rapid labor force growth rates and relatively slow employment growth cause unemployment problems in developing countries. The high level of unemployment, the extent of poverty, and the uneven distribution of income have interrelated relationships. For those workers who do not have a regular job, or only have part time work is always among the group of the very poor society. They who working on a fixed wage in the public and private sectors are usually among in the group of the middle and upper class society. However, it is wrong to assume that everyone who does not have a job is poor, while a full-time worker is a rich man. The poor society generally face the problems of limited the job opportunities, limited chance for business development, the weakening of the protection to business assets, the difference in wages, and the lack of job protection, especially for child laborers and female workers, such as female migrant workers and domestic workers. Therefore, one of the main mechanisms for reducing poverty and inequality of income

\section{Research Method}

This research uses two type of variables are dependent variable and independent variable. Dependent variable in this research is poverty that there are in South Sumatera Province by city and district in year 2013-2018. While the independent variables in this study are Gross Regional Domestic Product (PDRB), education and unemployment that there are in South Sumatra by city and district in 2013-2018.

The data used in this research is secondary data which is a combination of time series (time series) from 2013-2018 and a series of latitude (cross section) as much as 17 datas representing cities and counties in South Sumatra, which produces 140 observations. The data and data distribution in developing countries is to provide adequate wages and provide employment opportunities for poor communities [8].

Therefore, the government can do various plans to fulfill the right of the poor society to decent work and business development in order to reduce the unemployment rate. These plans include:

1. Improving the effectiveness and institutional capacity of government in upholding industrial relations that human.

2. Improving global partnerships in order to expand employment opportunities and increase job protection.

3. Increase the knowledge and skills of the poor society in order to develop work and business skills.

4. Improving the protection to domestic and foreign migrant workers.

Based on these facts, so it is necessary to do research about effect of GDP, education level and unemployment to poverty in the province of South Sumatra during the last six years by the title Analysis of the Influence of GDP, Education And Unemployment To Poverty In South Sumatra Province Year 2013-2018. The purpose of this research is want to know: (1) The negative effect of PDRB to poverty in South Sumatera province 2013-2018, (2) Negative influence of education level to poverty in South Sumatera Province 2013-2018, (3) The negative effect of unemployment rate to Poverty in South Sumatra Province in 2013-2018.

sources used as a reference for the purposes of the analysis are:

1. Data percentage of the amount of area poor people for each cities and counties in the province of South Sumatra, 2013-2018, from the Central Statistics Agency (BPS) in the Data publication and Information Poverty.

2. Data percentage rate of Gross Domestic Product (GDP) at constant prices for each city and district in South Sumatra 2013-2018, it is from the Central Statistics Agency (BPS) in the publication of the GDP of South Sumatra.

3. Data percentage education level that proxy with the literacy rate of the respective cities 
and districts in South Sumatra 2013-2018, ie from the Central Statistics Agency (BPS) in publication South Sumatra in Figures .

4. The data percentage of open unemployment amount for each city and district in South Sumatra in 2013-2018, it is from the Central Statistics Agency (BPS) in the publication of Labor Force condition in the state of South Sumatra Province.
The data used to achieve the objectives in this study obtained through literature study as a method of data collection, so no sampling technique or questionnaire required. Period of data used in this study is the year 2013-2018. For data analysis, data panel analysis is used as a data processing tool using Eviews program, with a combination of time series and cross-section data.

$$
\mathrm{Yi}=\boldsymbol{\beta 0}+\boldsymbol{\beta 1 X i}+\varepsilon \mathbf{i}
$$

$\mathrm{I}=1,2, \ldots, \mathrm{N}$

where $\mathrm{N}$ is the number of cross-section data While the model equations with time-series are:

$$
Y t=\beta 0+\beta 1 X t+\varepsilon t
$$

$\mathrm{t}=1,2, \ldots, \mathrm{T}$

where $\mathrm{T}$ is the number of time-series data

As we know that panel data is a combination of time-series and cross-section, the model can be written as follows:

$\mathrm{I}=1,2, \ldots, \mathrm{N} ; \mathrm{t}=1,2, \ldots, \mathrm{T}$

$$
\text { Yit }=\beta 0+\beta 1 X i t+\varepsilon i t
$$

Where as:

$\mathrm{N}=$ number of observations

$\mathrm{T}=$ amount of time

$\mathrm{N} \times \mathrm{T}=$ number of panel data

In panel model analysis, it is done by two approaches: fixed effect approach and random effect approach. Fixed effect approach is done by entering dummy variable to allow to occur the differences parameter values both cross-section and time-series. The approach by including the dummy variable is known as the fixed effect model or Least Square Dummy Variable (LSDV). While the random effect approach is done because the decision to include the dummy variable in the fixed effect model will cause a trade off effect. The addition of this dummy variable will be able to reduce the number of degrees of freedom which will ultimately reduce the efficiency of the estimated parameters. Panel data model that involving correlation between error term because changing time and observation can be overcome by component model approach (error component model) or also called random effect model.

There are four key considerations for choosing between using a fixed effect approach, and a random effect approach in panel data:

1. If the number of time-series (T) is large while the number of cross-section $(\mathrm{N})$ is small, then the result of fixed effect and random effect is not much different so it can be chosen approach that easier to calculate the fixed effect model (FEM).

2. If the cross-section (N) is large and the timeseries $(\mathrm{T})$ is small, then the result of the estimation of the two approaches will differ greatly. Thus, if the selected cross-section unit in the study is taken randomly, so a random effect should be used. If the crosssection unit selected in the study is not taken randomly then it can use fixed effect.

3. If the individual error component $\varepsilon i$ is correlated then the random effect estimator will be biased and the fixed effect estimator is not biased.

4. If the large cross-section (N) and time-series (T) are small, and the underlying assumption of random effect can be fulfilled, the use of the random effect model is more efficient than the fixed effect model. 


\section{Results and Analysis}

\subsection{Description Area}

South Sumatra Province is a province of Indonesia. It is located in the southern part of Sumatra Island, east of the Bukit Barisan Mountains. It spans $91,592.43 \mathrm{~km} 2(35,364 \mathrm{sq} \mathrm{mi})$ and had a population of estimate is $10,675,862$. The capital of the province is Palembang.This province divided into 14 regencies and four autonomous cities. The province is located in the southeastern portion of the island of Sumatra. The majority of its area consists of low-lying plains filled with plantations, forest, marshes and mangroves in coastal areas. The natural environment of South Sumatra is hot and humid tropical rain forest. However, most of these forest has been cleared out to make way for oil palm plantation for palm oil production. The Bukit Barisan mountain range is located on the western edge of the province and forms the border with the neighbouring Bengkulu province. The mountains are the source of river systems that drain eastward to the Bangka Strait and South China Sea. The largest among these rivers is Musi River, the longest river in Sumatra.

The administrative area of the province borders the provinces of Lampung to the south, Bengkulu to the west, and Jambi to the north. Off the east coast are the islands of Bangka and

\subsection{Description of Poverty}

Poverty data shows that the percentage of poor people of South Sumatera Province in 2013-
Belitung, which were split from South Sumatra province to form the new province of BangkaBelitung in 2000. The climate of South Sumatra is quite suitable for palm oil industries, including palm estate and rubber industries.According to a 2015 estimate, South Sumatra has a population of $10,675,862$. Its population had tripled from 1971 to 2015 , not counting the population lost due to the creation of Bangka Belitung province in 2000.

The province has no clear ethnic dominance, though the indigenous Musi-speaking Malays have a plurality, followed by the Javanese, most of whom recent migrants from Java as part of the government-sanctioned transmigration project created to balance the population, especially from the highly overpopulated Java island; as a result, Javanese is also widely spoken and understood, especially in area with high population of transmigrant, for example Belitang. Forming the next largest group is the other Malayan-speaking populations as well as the Komering, a distinct Malayo-Polynesian people related to the native Lampungese from neighboring Lampung. Minangkabau, Chinese, and Sundanese also form minorities in the province.

2018 is highest in Empat Lawang Regency which is 17.49 percent in 2018 .

Tabel 1.Data Percentage Poverty South Sumatra Year 2013-2018

\begin{tabular}{clcccccc}
\hline No. & \multicolumn{1}{c}{ City / Regency } & $\mathbf{2 0 1 3}$ & $\mathbf{2 0 1 4}$ & $\mathbf{2 0 1 5}$ & $\mathbf{2 0 1 6}$ & $\mathbf{2 0 1 7}$ & $\mathbf{2 0 1 8}$ \\
\hline 1 & Banyuasin Regency & 12.69 & 12.76 & 12.83 & 12.88 & 12.34 & 11.29 \\
2 & Empat Lawang Regency & 12.02 & 12.34 & 12.36 & 12.83 & 17.62 & 17.49 \\
3 & Lahat Regency & 13.05 & 13.89 & 13.69 & 13.08 & 21.62 & 11.44 \\
4 & Muara Enim Regency & 11.63 & 11.85 & 11.36 & 11.69 & 12.20 & 12.33 \\
5 & Musi Banyuasin Regency & 13.65 & 13.50 & 13.06 & 13.88 & 14.40 & 15.30 \\
6 & Musi Rawas Regency & 15.15 & 15.83 & 15.49 & 15.30 & 15.80 & 15.58 \\
7 & Musi Rawas Utara Regency & 17.50 & 17.03 & 17.40 & 17.14 & 17.08 & 16.38 \\
8 & Ogan Ilir Regency & 16.00 & 16.50 & 16.04 & 16.74 & 16.80 & 16.64 \\
9 & Ogan Komering Ilir Regency & 13.79 & 13.75 & 13.34 & 13.35 & 13.74 & 13.78 \\
10 & Ogan Komering Ulu Regency & 14.14 & 14.69 & 14.39 & 14.68 & 14.56 & 14.55 \\
11 & Ogan Komering Ulu Selatan Regency & 14.83 & 14.49 & 14.25 & 14.87 & 15.04 & 14.75 \\
12 & Ogan Komering Ulu Timur Regency & 11.06 & 11.59 & 11.70 & 11.87 & 12.23 & 12.28 \\
13 & Penukal Abab Lematang Ilir Regency & 17.48 & 17.99 & 17.27 & 17.72 & 17.45 & 17.08 \\
14 & Lubuk Linggau City & 14.93 & 14.05 & 14.73 & 14.58 & 14.15 & 12.68 \\
15 & Pagar Alam City & 15.42 & 15.36 & 15.37 & 15.49 & 15.53 & 15.56
\end{tabular}




\begin{tabular}{clcccccc}
\hline No. & \multicolumn{1}{c}{ City / Regency } & $\mathbf{2 0 1 3}$ & $\mathbf{2 0 1 4}$ & $\mathbf{2 0 1 5}$ & $\mathbf{2 0 1 6}$ & $\mathbf{2 0 1 7}$ & $\mathbf{2 0 1 8}$ \\
\hline 16 & Palembang City & 12.82 & 12.14 & 12.79 & 12.90 & 12.95 & 12.32 \\
17 & Prabumulih City & 12.35 & 12.40 & 12.18 & 12.34 & 12.25 & 11.72 \\
\hline
\end{tabular}

Source:BPS (2019)

Data and Information of Poverty South Sumatera

\subsection{Gross Regional Domestic Product (GRDP)}

From the data of GDP growth rate, indicating that the rate of PDRB that occurred in towns and districts in South Sumatera province in

2013-2018 shows a fluctuating number of each region. The rate of GDP can show the economic condition in South Sumatra:

Table 2. Percentage Data of GDP Growth of South Sumatera Year 2013-2018

\begin{tabular}{clcccccc}
\hline No. & \multicolumn{1}{c}{ City/Regency } & $\mathbf{2 0 1 3}$ & $\mathbf{2 0 1 4}$ & $\mathbf{2 0 1 5}$ & $\mathbf{2 0 1 6}$ & $\mathbf{2 0 1 7}$ & $\mathbf{2 0 1 8}$ \\
\hline 1 & Banyuasin Regency & 4.33 & 4.72 & 4.87 & 4.92 & 4.69 & 4.48 \\
2 & Empat Lawang Regency & 3.21 & 4.48 & 5.30 & 5.41 & 5.13 & 4.88 \\
3 & Lahat Regency & 4.18 & 5.06 & 6.19 & 5.30 & 5.03 & 4.79 \\
4 & MuaraEnim Regency & 4.95 & 5.35 & 6.01 & 5.98 & 5.74 & 5.53 \\
5 & Musi Banyuasin Regency & 5.20 & 5.08 & 5.52 & 5.61 & 5.31 & 5.04 \\
6 & Musi Rawas Regency & 4.85 & 5.23 & 6.08 & 5.62 & 5.32 & 5.05 \\
7 & Musi Rawas Utara Regency & 3.19 & 3.23 & 3.58 & 3.69 & 3.56 & 3.44 \\
8 & Ogan Ilir Regency & 4.62 & 4.91 & 5.21 & 4.99 & 4.75 & 4.54 \\
9 & Ogan Komering Ilir Regency & 4.08 & 4.19 & 4.09 & 4.04 & 3.88 & 3.73 \\
10 & Ogan Komering Ulu Regency & 4.59 & 2.30 & 3.31 & 3.93 & 3.78 & 3.64 \\
11 & Ogan Komering Ulu Selatan & 4.11 & 4.53 & 5.11 & 4.84 & 4.62 & 4.42 \\
12 & Ogan Komering UluTimur & 4.31 & 4.07 & 5.07 & 4.27 & 4.09 & 3.93 \\
13 & Penukal Abab Lematang Ilir & 3.49 & 4.08 & 4.74 & 4.75 & 4.43 & 4.15 \\
14 & LubukLinggau City & 5.16 & 5.18 & 5.73 & 5.69 & 5.38 & 5.11 \\
15 & Pagar Alam City & 4.74 & 4.00 & 4.37 & 5.33 & 5.06 & 4.81 \\
16 & Palembang City & 6.07 & 6.85 & 6.95 & 6.62 & 6.32 & 6.06 \\
17 & Prabumulih City & 3.56 & 5.53 & 3.81 & 4.67 & 4.46 & 4.27 \\
\hline Source $B P S(2019)$ & & & & & &
\end{tabular}

Source:BPS (2019)

PDRB SouthSumatera2013-2018

\subsection{Education (Literacy)}

From the literacy rate data shows that the literacy rate of South Sumatera province in 20132018, the biggest is in the city of Palembang

which is 88.30 percent in 2018 and the lowest is in Penukal Abab Lematang Ilir regency which is 60.10 percent in 2013.

Table3. Percentage of Education Data (Literacy Rate) Population of South Sumatra Age 14 and Up Year 2013-2018

\begin{tabular}{llcccccc}
\hline No. & City/Regency & $\mathbf{2 0 1 3}$ & $\mathbf{2 0 1 4}$ & $\mathbf{2 0 1 5}$ & $\mathbf{2 0 1 6}$ & $\mathbf{2 0 1 7}$ & $\mathbf{2 0 1 8}$ \\
\hline 1 & Banyuasin Regency & 67.45 & 68.30 & 68.70 & 700.42 & 71.35 & 72.28 \\
2 & EmpatLawang Regency & 68.45 & 68.80 & 69.05 & 68.71 & 68.96 & 68.62 \\
3 & Lahat Regency & 72.05 & 72.30 & 73.30 & 72.21 & 73.21 & 72.12 \\
4 & MuaraEnim Regency & 70.40 & 70.75 & 71.15 & 70.66 & 71.06 & 70.57 \\
5 & MusiBanyuasin Regency & 66.85 & 67.15 & 68.10 & 67.06 & 68.01 & 66.98
\end{tabular}




\begin{tabular}{clcccccc}
\hline 6 & MusiRawas Regency & 69.40 & 69.75 & 70.10 & 69.66 & 70.01 & 69.57 \\
7 & MusiRawas Utara Regency & 67.85 & 68.20 & 68.35 & 68.11 & 68.26 & 68.02 \\
8 & OganIlir Regency & 67.45 & 67.80 & 68.30 & 67.71 & 68.21 & 67.63 \\
9 & OganKomeringIlir Regency & 69.55 & 69.90 & 70.30 & 69.81 & 70.21 & 69.72 \\
10 & OganKomeringUluRegency & 75.10 & 75.65 & 76.60 & 75.56 & 76.51 & 75.48 \\
11 & OganKomeringUlu Selatan & 73.00 & 73.35 & 69.35 & 69.27 & 69.26 & 73.18 \\
12 & OganKomeringUluTimur & 68.40 & 68.90 & 70.20 & 68.81 & 70.11 & 68.72 \\
13 & PenukalAbabLematangIlir & $\mathbf{6 0 . 1 0}$ & 60.35 & 61.40 & 60.27 & 61.32 & 65.20 \\
14 & LubukLinggau City & 72.05 & 72.50 & 74.25 & 72.42 & 74.17 & 72.34 \\
15 & PagarAlam City & 75.20 & 76.45 & 81.25 & 76.37 & 81.17 & 76.30 \\
16 & Palembang City & 85.15 & 85.35 & 88.35 & 85.26 & 88.26 & $\mathbf{8 8 . 3 0}$ \\
17 & Prabumulih City & 78.75 & 78.95 & 81.50 & 78.87 & 81.42 & 78.79 \\
\hline
\end{tabular}

Source:BPS (2016), processed

\subsection{Unemployment}

From the unemployment rate data shows that the level of unemployment in South Sumatra province in is the largest in the city of
Palembang is 6.81 percent in 2017 and the lowest is in the Lubuklinggau city of 5.10 percent in 2016.

Table 4. Percentage of South Sumatra Unemployment in 2013-2018

\begin{tabular}{llcccccc}
\hline \multicolumn{1}{c}{ No. } & \multicolumn{1}{c}{ City/Regency } & $\mathbf{2 0 1 3}$ & $\mathbf{2 0 1 4}$ & $\mathbf{2 0 1 5}$ & $\mathbf{2 0 1 6}$ & $\mathbf{2 0 1 7}$ & $\mathbf{2 0 1 8}$ \\
\hline 1 & Banyuasin Regency & 6.61 & 5.82 & 5.39 & 5.91 & 6.11 & 5.46 \\
2 & EmpatLawang Regency & 6.72 & 5.36 & 6.07 & 6.05 & 6.25 & 5.82 \\
3 & Lahat Regency & 6.80 & 5.33 & 6.13 & 5.77 & 6.30 & 5.97 \\
4 & Muara Enim Regency & 6.60 & 5.94 & 5.92 & 5.71 & 5.52 & 5.34 \\
5 & Musi Banyuasin Regency & 6.94 & 5.27 & 6.25 & 5.90 & 5.51 & 5.48 \\
6 & Musi Rawas Regency & 6.23 & 5.53 & 6.01 & 5.92 & 6.09 & 6.02 \\
7 & Musi Rawas Utara Regency & 6.76 & 5.27 & 6.48 & 6.16 & 5.91 & 5.52 \\
8 & Ogan Ilir Regency & 6.77 & 5.66 & 6.04 & 5.64 & 5.32 & 6.05 \\
9 & Ogan Komering Ilir Regency & 6.49 & 5.30 & 5.83 & 6.19 & 5.84 & 5.70 \\
10 & Ogan Komering Ulu Regency & 6.16 & 5.40 & 5.78 & 5.76 & 6.19 & 5.38 \\
11 & Ogan Komering Ulu Selatan Reg. & 6.69 & 5.79 & 5.63 & 5.70 & 5.96 & 5.33 \\
12 & Ogan Komering Ulu Timur Reg. & 6.17 & 5.61 & 6.18 & 6.12 & 5.45 & 5.65 \\
13 & Penukal Abab Lematang Ilir Reg. & 6.15 & 5.45 & 5.42 & 5.39 & 5.87 & 5.86 \\
14 & LubukLinggau City & 6.73 & $\mathbf{5 . 1 0}$ & 6.19 & 6.26 & 5.36 & 5.52 \\
15 & PagarAlam City & 6.76 & 5.14 & 6.03 & 6.15 & 5.31 & 5.67 \\
& & & & & & & \\
\hline \hline
\end{tabular}




\begin{tabular}{llrrrrrr}
\hline No. & City/Regency & $\mathbf{2 0 1 3}$ & $\mathbf{2 0 1 4}$ & $\mathbf{2 0 1 5}$ & $\mathbf{2 0 1 6}$ & $\mathbf{2 0 1 7}$ & $\mathbf{2 0 1 8}$ \\
\hline 16 & Palembang City & 6.62 & 5.15 & 6.26 & 6.56 & $\mathbf{6 . 8 1}$ & 6.55 \\
17 & Prabumulih City & 5.49 & 5.50 & 6.38 & 6.36 & 6.53 & 6.11 \\
\hline
\end{tabular}

Source: BPS (2019)

Source: Labor Force Situation of South Sumatera Province 2013-2018

\subsection{Tables and Equations}

The equation model of the influence of GDP, Education and Unemployment on Poverty in the city and district of South Sumatra Province are as follows:

$$
\mathrm{Y}=\mathrm{AX} 1+\mathrm{BX} 2+\mathrm{CX} 3
$$

Where:

Y : Poverty

X3 : Unemployment

$\mathrm{X} 1 \quad$ : GRDP $\quad$ A, B, C : Coefficient

$\mathrm{X} 2$ : Education (literacy)

\section{Data Processing Panel with E-Views Fixed Effect model estimation (FEM)}

In this estimate, F-Test and Chi-Square testing are done. If $\mathrm{p}$-value is less than $5 \%$ then $\mathrm{H}_{0}$ is rejected and $\mathrm{H}_{1}$ is accepted. The otherwise, $\mathrm{H}_{0}$ : model follows model pool. $\mathrm{H}_{1}$ : the model follows the Fixed model

Fixed model estimation results are as follows:

Table 5. Regression Results The Effect of GDP, Education and Unemployment on Poverty in South Sumatera 2013-2018 by using Fixed Model.

\begin{tabular}{cllll}
\hline Variable & Coefficient & Std. Error & t-Statistic & Prob \\
\hline \hline C & 6.213633 & 0.618946 & 10.03905 & 0.0000 \\
PDRB & -0.309007 & 0.048795 & -6.332746 & 0.0000 \\
Unemployment & 1.612221 & 0.030235 & 53.32272 & 0.0000 \\
MLKHRF & -0.016232 & 0.003173 & -5.115069 & 0.0000 \\
\hline
\end{tabular}

\section{Effect Specification}

Cross-section fixed (dummy variables)

\begin{tabular}{lllr}
\hline \hline R-squared & 0.993044 & Mean dependent var. & 21.53400 \\
Adjusted R-squared & 0.992219 & S.D. dependent var. & 7.796268 \\
S.E. of regression & 0.687687 & Akaike info criterion & 2.191248 \\
Sum squared resid & 147.5491 & Schwarz criterion & 2.610109 \\
Log likehood & -345.4684 & Hannan-Quinn criterion 2.357970 \\
F-statistic & 1203.882 & Durbin-Watson statistic 2.112519 \\
Prob (F-statistic) & 0.000000 & & \\
\hline
\end{tabular}

Source: Eviews Data Processing 
While the results of Redundant Fixed Effects tests are as follows:

Tabel 6. The Results of Redundant Fixed Effects testsin Fixed Model.

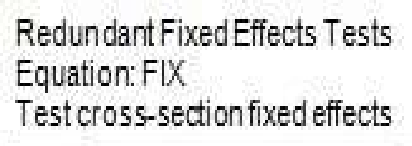

\begin{tabular}{llll}
\hline Effects Test & Statistic & d.f. & Prob. \\
\hline \hline Cross-sectionF & 1.843347 & $(34,312)$ & 0.0039 \\
Cross-sectionChi-square & 64.068403 & 34 & 0.0014 \\
\hline \hline
\end{tabular}

Source: Eviews Data Processing

From the above test results, obtained the value of Cross-section F of 0.0039 and Crosssection Chi-square of 0.0014 . This value is less than 5\% (0.05). So, $\mathrm{H}_{0}$ is rejected and accepts $\mathrm{H}_{1}$, and the model follows the fixed model.

\section{Estimation of Random Effect (REM) model}

In this estimate, the Hausman test (Hausman test) is performed. If p-value is less than 5\% then $\mathrm{H} 0$ is rejected and $\mathrm{H} 1$ is accepted. The otherwise, $\mathrm{H}_{0}$ : the model follows a random model. $\mathrm{H}_{1}$ : the model follows the fixed model. Random model estimation results are as follows:

Table 7. Regression Results Effect of GDP, Education and Unemployment on Poverty in South Sumatera 2010-2015 by using Random Model.

\begin{tabular}{clllll}
\hline Variable & \multicolumn{2}{c}{ Coefficient } & Std. Error & t-Statistic & Prob \\
\hline \hline C & 2.477077 & 0.399146 & 6.205949 & 0.0000 \\
PDRB & -0.122596 & 0.024178 & -5.070643 & 0.0000 \\
Unemployment & 1.802214 & 0.016921 & 106.5077 & 0.0000 \\
MLKHRF & -0.008722 & 0.002599 & -3.375293 & 0.0000 \\
\hline
\end{tabular}

Effect Specification

S.D Rho.

\begin{tabular}{lll}
\hline Cross-section random & 0.000000 & 0.0000 \\
Idiosyncratic random & 0.687687 & 1.0000
\end{tabular}

Weighted Statistics

Cross-section fixed (dummy variables)

\begin{tabular}{llll}
\hline R-squared & 0.99164 & Mean dependent var. & 21.53400 \\
Adjusted R-squared & 0.991575 & S.D. dependent var. & 7.796268 \\
S.E. of regression & \multicolumn{2}{c}{0.715615} & Sum squared residual $\quad 177.1884$ \\
F-statistic & 13692.28 & Durbin-Watson statistic 2.038427 \\
Prob (F-statistic) & 0.000000 & & \\
\hline
\end{tabular}


Unweighted Statistics

\begin{tabular}{lllr}
\hline R-squared & 0.991647 & Mean dependent variable & 21.53400 \\
Sum squared residual & 177.1884 & Durbin-Watson statistic 2.038427
\end{tabular}

Source: Eviews Data Processing

While the results of Redundant Fixed Effects tests are as follows:

Tabel 8. The Result of Hausman-tests in Random Model.

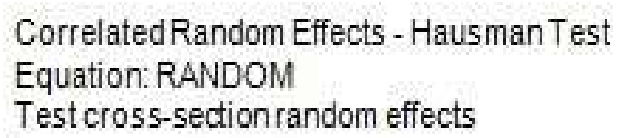

\begin{tabular}{llcc}
\hline \hline \multicolumn{4}{l}{ Chi-Sq. } \\
& & \\
\hline Test Summary & Statistic & Chi-Sq. d.f. & Prob. \\
Cross-sectionrandom & 62.592205 & 3 & 0.0000 \\
\hline
\end{tabular}

Source: Eviews Data Processing

From the results of the above test, obtained the value of Cross-section random 0,0000 it is smaller than $5 \%(0.05)$. So $\mathrm{H}_{0}$ is rejected and accepts $\mathrm{H}_{1}$, and the model follows the fixed model.

\subsection{Hypothesis}

Regression equation influence of GDP, Education and Unemployment to Poverty in South Sumatera in 2013-2015 with panel data processing, are as follows:

POVERTY $=6,214-0,309 *$ GRDP $+1,612 *$ UNDERSTANDING $-0,016 *$ EDUCATION (5)

\section{GRDP and Poverty}

GRDP variable shows negative sign and significantly influence to Poverty in South Sumatera. An increase in open unemployment rate of 1 (one) does not increase poverty, but the results of this study will reduce poverty by 0.309 . The results are in accordance with the theories of Novaless at al., (2015) and Tambunan (2009), which form the theoretical basis in this study where growth and poverty have a very strong correlation, because in the early stages of development process poverty tends to increase and when approaching the final stage development, the number of poor people gradually diminished. This shows the importance of accelerating economic growth to reduce the number of poor people. With the rapid economic growth will reduce the number of poverty which is one of the indicators of success of regional development.

\section{Education and Poverty}

Educational variables that are proxyed by the level of literacy indicate a negative sign and significantly influence the unemployment rate in South Sumatra. The increase of literacy rate as education indicator in South Sumatera by one will decrease poverty by 0,016 . Which means that an increase in literacy rate will reduce poverty in Central Java. The results are in accordance with previous theories and research that became the theoretical foundation in this study. According to Todaro \& Stephen (2015), education is a way to save yourself from poverty. A poor man who expects good employment and high income should have a high level of education. However, higher education can only be achieved by the rich. Meanwhile, the poor do not have sufficient funds to finance education to a higher level, such as secondary schools and universities.

\section{Unemployment and Poverty}

From the results of regression generated in this study, showed that the unemployment variable showed a positive sign and significantly influence the poverty in South Sumatra. An 
increase in open unemployment rate of one does not reduce poverty but from the results of this study actually increase the poverty as much as 16.12. These results are not in accordance with the theory and previous research that became the theoretical basis in this study. Based on data from the Central Bureau of Statistics (BPS) of South Sumatra, the number of open unemployment in South Sumatera in 2018 reached 1.23 million people and increased unemployment from year to year. The number of job seekers in Central Java is 689,415 people, while there are 92,357 inhabitants. Thus, as many as 597,05 souls are absorbed into the informal sector and looking for jobs outside the city. In addition, some are trying or preparing to open their own businesses, some are waiting to start work, and others are included into the open unemployment category.

\section{Conclusions}

The effect of variables GDP, Education (literacy) and unemployment to poverty by city and district in South Sumatra Province in 20132018. The conclusions of the results of this study are:

1. GDP variables have a negative influence and significantly affect to the poverty. This is because the increase of the PDRB in South Sumatra is followed by the decrease of poverty in South Sumatra.

2. Education Variables (literacy) have a negative influence and significantly affect to the poverty. This is because the increase of literacy rate in South Sumatra Province is followed by the decrease of poverty.

3. Variables Unemployment has a positive and significant influence affect to the poverty. This is because the increase of unemployment in South Sumatra is followed by increasing poverty.

Based on the results of the discussion and conclusion, it can be given suggestions as follows:

1. Economic growth affect the level of poverty, the government is expected to do development oriented on the equity of income and equity of economic results to all groups of society, and efforts to increase economic growth in each region by relying on potentials which are owned.

2. From the results of the study, the level of education has a negative and significant influence on poverty, so it is expected the government of South Sumatra province again add illiteracy eradication program in order to suppress poverty in all cities and districts in South Sumatra. Beside the government should provide educational guarantees for people Poor and improving educational facilities equally not only concentrated in an area but evenly distributed throughout the region

3. Based on the results of the study, the unemployment rate has a positive and significant effect on poverty. With the result, it is expected that South Sumatera Provincial Government will further drive the economic sector so that it can open employment in South Sumatera. This is based on the results of research where unemployment has a large influence on poverty, so with the increasingly wide employment, unemployment will be reduced and poverty will also be reduced.

4. The model that developed in this study is still limited, because it only sees the effect of the GDP, education and unemployment variables on poverty in South Sumatera Province.Therefore, further in-depth study is required with more complete data and methods so as to complement the results of research has existed and the results can be used as a consideration for various parties related to economic development in terms of poverty reduction.

\section{References}

[1] S. M. S. Arthur O'sullivan, Prentice Hall Economics: Principles in Action. New Jersey: Pearson Prentice Hall, 2007.

[2] Sardiyo and M. Dhasman, "Globalization and Its Impact On Economic Growth," Ekuilibrium J. Ilm. Bid. Ilmu Ekon., vol. 14, no. 2, pp. 104-119, 2019. 
[3] Badan Pusat Statistik, Data dan Informasi Kemiskinan Sumatera Selatan, Palembang: Dokumen BPS, 2019.

[4] Ahking, Francis W, Economic Growth, USA: University of Cennecticut, 2013.

[5] Todaro, MichaelP \& Stephen C. Smith, Economic Development, 12th edition, New Jersey: Pearson Prentice Hall, Upper Saddle River, 2015.

[6] Mankiw, N. Gregory, Macroeconomics, $9^{\text {th }}$ edition, Worth Publishers, New York: A Macmillan Education imprint, 2016.

[7] Novales, Alfonso, Fernández, Esther, Ruíz, Jesús, Economic Growth: Theory and Numerical Solution Methods. Berlin Heidelberg: Springer-Verlag, 2015.

[8] Arsyad, Lincolin, Ekonomi Pembangunan, Yogyakarta: STIM YKPN, 2010.

[9] Tulus Tambunan, SME development, economic growth, and government intervention in a developing country: The Indonesian story, Journal of International Entrepreneurship, Volume 6 issue 4 p.147167, Springer US, 2009.

[10] Badan Pusat Statistik, PDRB Kabupaten/Kota Provinsi Sumatera Selatan Tahun 2013-2018. Palembang: Dokumen BPS, 2019.

[11] Gujarati, Damodar\& Dawn C. Porter, Basic Econometrics, International Edition, United States: McGraw-Hill Education, 2010.

[12] Spicker, Paul, Poverty and Social Security: Concept and principles, Retrieved from https://openair.rgu.ac.uk/handle/10059/89 ‥ 2013. 